УДК 343.13

DOI https://doi.org/10.32837/pyuv.v1i4(29).424

\author{
Ю. В. Циганюк \\ orcid.org/0000-0002-8495-3583 \\ кандидат юридичних наук, адвокат, \\ завідувач кафедри права та правоохоронної ділльності \\ Хлельницького інституту \\ Міжрегіональної Акаделї̈ управління персоналол
}

\title{
ОКРЕМІ ОЗНАКИ РЕЛІГІЙНО-ТРАДИЦІЙНОГО ТИПУ СИСТЕМИ КРИМІНАЛЬНОГО ПРОЦЕСУ
}

Сучасний світ повністю залежний від інтеграційних процесів. Вони відбуваються у суспільній, державній, а також правовій сфері. Світове співтовариство переважно підтримує такі процеси, адже вони взаємно пов'язані та залежні одні від інших. Процеси глобалізації та інтеграції відбуваються у різних правових системах, що створює окремі наукові проблеми для їх вивчення, в тому числі юридичною наукою. Досліджуються спільні та відмінні риси. Одним із таких досліджень необхідно презентувати аналіз окремих ознак релігійно-традиційного типу кримінального процесу за допомогою ізолюючої абстракції самостійних і нетипових для континентальної системи кримінального процесу елементів.

Окремі елементи релігійно-традиційного типу системи кримінального процесу віднайшли своє місце у працях Ю.П. Аленіна, І.В. Гловюк, М.Л. Грібова, О.М. Дроздова, О.В. Капліної, Д.Б. Кастарнова, О.М. Коваль, О.П. Кучинської, М.А. Погорецького, О.Г. Шило, О.Г. Яновської, M.M. Шумило та інших правників-науковців. Однак узагальненого дослідження з виокремленням ознак релігійно-традиційного типу системи кримінального процесу в контексті встановлення їх системності не було. Отже, метою статті є аналіз окремих ознак релігійно-традиційного типу системи кримінального процесу. У цій статті ми звернемо увагу на нетипові для кримінального процесу України правові явища або їх елементи, що існують у країнах релігійно-традиційної системи права.

У Індії кодифікація вивела на поверхню внутрішню напруженість у лібералізмі та імперії. Парадокс спроб створити демократичні правові інститути в умовах абсолютного авторитаризму проявився 3 яскравою чіткістю в дискусіях про Кримінально-процесуальний кодекс. Хороші ідеї в теорії, юридична рівність та однакова кримінальна юрисдикція були оголошені неприйнятними в умовах особливих обставин Індії, коли різні культури робили поняття «рівність» відносним, а не абсолютним принципом. Є. Кольська визначила, що для задоволення цих особливих обставин було вироблено спеціальне законодавство, яке підкреслює багатовимірність колоніальної різниці [1, с. 683].
Про таку ж ситуацію зазначають у наукових джерелах щодо Республіки Малаві. Попри рівність, на яку люди мають право перед законом, на практиці доступ до правосуддя не працює саме так, як каже теорія [2, с. 1]. Комісія з прав людини у Малаві назвала систему кримінального правосуддя країни слабкою, посилаючись на справедливість, та компрометованою через занадто велику кількість архаїчних законів про статутні книги й відмову від правосуддя з огляду на відсутність законного представництва для корінних народів [2, с. 1]. У Малаві винаймання приватних адвокатів є дуже дорогим навіть для тих людей, які мають вищий економічний статус [2, с. 2].

Що стосується Японії, то японська правова система справді унікальна. Це суміш цивільної і загальноправової систем, яка була прищеплена до системи, заснованої на звичаях та цінностях, які протягом століть мали першорядне значення в Японії та нині залишаються яскравими. У багатьох інших аспектах їхньої системи японці досягли надзвичайного успіху в запозиченні особливостей закордонних правових систем, не жертвуючи власними корінними цінностями [3, с. 538]. На те, що вказана система є конгломератом двох типів правових систем - континентальної та англоамериканської - також вказує С.А. Соловйов [4, с. 232].

Занадто рано судити про те, наскільки ефективним є новий Кодекс (далі - КПК) у досягненні його мети, якою є встановлення процедури, яка роз'яснювала б справжні факти кримінальних справ і застосовувала б та виконувала б кримінальне законодавство справедливо та швидко, щоб підтримувати громадський добробут та забезпечувати основні права людини щодо різних осіб. Його реформи грунтуються на потребах, виявлених японською історією, а також на правових ідеях, розроблених за допомогою багатовікового досвіду в інших країнах, які були адаптовані та інтегровані в японську легальну систему. Немає сумнівів, що його прийняття стало важливим кроком у напрямку свободи людини та верховенства права в Японії [5, с. 429-430].

Прикладом традиціоналізму можна назвати те, що, за словами П.М. Бірюкова, в Японії існує заборона на виконання обшуку в приміщенні, 
будівлі або на судні «до сходу сонця або після заходу сонця, якщо тільки в ордері не міститься письмова заява про те, що виконання вночі дозволено». Якщо виконання ордеру починалося до заходу сонця, воно може тривати й далі [6, с. 303].

У Китайській Народній Республіці (далі Китай) існують окремі традиції, що нами були дослідженні [7, с. 73-75], однак ми звернемо увагу ще на деякі особливості. Наприклад, адвокати не можуть зустрічатися і спілкуватися 3 клієнтами, які перебувають під вартою, і не можуть збирати докази за власною ініціативою. Після судового переслідування адвокати, як правило, мають менший доступ, ніж раніше, до інформації, зібраної обвинуваченням. Крім того, вони можуть бути притягнуті до кримінальної відповідальності за активний захист своїх клієнтів [8, р. 830-831]. Також відповідно до положень КПК Китаю адвокати можуть виконувати дві різні функції у кримінальному процесі, тобто надавати юридичну допомогу (falu zixun) та захисне представництво (daili bianhu) [8, c. 832].

Багато китайських науковців зазначало, що проблеми були притаманні старому КПК у зв' язку з інквізиційною системою, в якій судді виконували подвійну роль (як прокурора, так і судді). Однак КПК 1996 р. перетворив кримінально-процесуальний процес у Китаї з процесу інквізиційної системи в систему зі змішаними змагальними та інквізиційними елементами. Розвиток системи кримінального правосуддя свідчить про те, що політичні лідери в Китаї зараз врівноважують свій контроль за злочинністю з більшим акцентом на захист прав обвинувачених як відповідь на критику [9, с. 207].

Кодифікація як форма систематизації кримінального процесуального законодавства не так давно відбулась у країнах Латинської Америки. За останні 15 років 14 країн Латинської Америки та значна кількість латиноамериканських провінцій та штатів запровадили нові кримінально-процесуальні кодекси. Ці реформи - це, мабуть, найглибша трансформація, яку латиноамериканська кримінальна процедура зазнала протягом майже двох століть. Хоча реформи не були однаковими серед різних систем кримінального процесу, однак вони були описані реформаторами як перехід від інквізиції до звинувачувальної чи змагальної системи. Реформи мають багато характеристик, зокрема i запровадження громадських судових процесів, запровадження та / або посилення посади прокуроpa, рішення про призначення прокурора замість судді, відповідального за досудове слідство. Інші зміни включають надання обвинуваченим більших прав на етапах досудового провадження, введення принципу прокурорського розсуду, забезпечення можливості укладання угоди про визнання вини та альтернативних механізмів вирішення спорів, розширення ролі захисту жертви під час кримінального процесу [10, с. 619-620].

Ісламський кримінальний процес виник, розвивався і сформувався як специфічний (суддівський) засіб розгляду справ про злочини і покарання, що виникають в двох основних сферах суспільних відносин у мусульманському співтоваристві. Це відносини віруючих з Аллахом i відносини між людьми (в тому числі й між правовірними мусульманами і немусульманами, які проживають на території мусульманської громади або держави). Порядок розгляду таких справ є судовим порядком вирішення правових спорів взагалі (здійснення правосуддя у будь-яких справах), тому він регламентується (поряд з питаннями про призначення на суддівські посади, організацію та компетенцію судів) нормами мусульманського судового права [11, с. 204]. За словами П.А. Гусьонової, кримінальний процес Ісламської Республіки Іран і Королівства Саудівська Аравія за своїми релігійно-правовими характеристиками відносять до ісламського типу, а за загальними і функціональними характеристиками - до слідчого типу процесу [12, с. 130-131].

Наприклад, якщо говорити про гарантії справедливого судового розгляду у кримінальному провадженні з ісламського права, то конституційне законодавство Афганістану та міжнародне право - це спроба порівняння трьох дуже різних тем: 1) міжнародного права, що складається з обмеженої кількості міжнародних конвенцій більшменш точного формулювання, міжнародного звичаю, прийнятного як закон, загальних принципів права, що визнані цивілізованими націями, а також тлумачення цих джерел рішеннями суду та міжнародною науковою дискусією; 2) Конституції Афганістану як закону, який був прийнятий нещодавно; 3) ісламського закону, який розроблявся протягом століть, базуючись на Корані, Сунні (традиціях, які стосуються того, що Пророк сказав чи робив, або його мовчазного схвалення чогось сказаного чи зробленого в його присутності), Іджмі (консенсусі юристів) і Киясі (аналогії з Кораном і Сунною, проведеній юристами) або на їхніх головних джерелах, доповнених подальшими додатковими джерелами [13, с. 932].

Щоб точно зрозуміти ісламську систему кримінального правосуддя, її слід розглядати з урахуванням таких основних особливостей, що похідні від Корану та Сунни: а) те, що не є харамом (забороненим), є моба (дозволеним); b) правила та однозначні заборони часто базуються на справжніх подіях, а не на умовних ситуаціях (це збільшує можливість аналогічних міркувань); с) мова, що використовується у попередженнях, дозволяє розробляти та впроваджувати політику, що спирається на обгрунтування політики та суспільної необхідності; d) експрес-мова, яка використовується у заборонах, 
часто використовується іншими текстами, які допускають виправдання особи разом із судовим розсудом; е) доказові передумови (передбачається обмежити розсуд суддів та посилити визнання підозрюваним своєї вини й застосовувати покарання щодо конкретних злочинних діянь) гарантують сувору сутність покарання; f) заборони кримінального правосуддя не зосереджені в жодній частині Корану і в Сунни, але поєднуються серед інших питань; g) створення процедурних гарантій покликане захистити особу від зловживань владою суддею та від інших зловживань, а також захистити права такої особи; h) кодифікація та законотворчість є прийнятними для всіх трьох класів правопорушень, при цьому дискреційне право допускається в кримінальних діях ta'azir; i) покарання за кожен вид злочину визначається окремо, підтверджуючи цим філософію та політику покарань; ј) вироки є засобами стримування, хоча окреме питання також приділяється реінтеграції здебільшого у злочинах ta'azir (зі стійкою тенденцією до компенсаційних санкцій (непокарання) у злочинах qisas та інших); k) питання про кримінальне правосуддя (злочини, покарання, доказові правила, процедури, судові процеси тощо) контекстно згадуються як частина різних віршів Корану, підкреслюючи соціальні та моральні аспекти кримінальної справедливості. Однак ці особливості залежать від обраного джерела права, його місця серед інших джерел та їх зв' язку згідно з чинними правилами інтерпретації, підкресленими наукою usul al-fiqh (ісламською юриспруденцією) [14, с. 2-3].

Однак духовну основу кримінального правосуддя, як і всього ісламського права, утворює Коран і Сунна. Саме в цих джерелах містяться найбільш загальні релігійні передумови ісламського кримінального правосуддя. Це такі передумови: закон і правосуддя походять від Бога; людське правосуддя висловлює суверенітет Бога, а не народу; милість Бога знаходиться в межах справедливості, а правосуддя є здійсненням справедливості у всіх сферах життя мусульманського суспільства [12, с. 127]. При цьому необхідно враховувати, що для багатьох немусульман сьогодні основним джерелом інформації про іслам і шаріат є засоби масової інформації. Але картинка, що транслюється там про шаріат як серію фіксованих, часто жорстоких правил, суттєво відрізняється від реальності [15, с. 96].

Специфічною особливістю кримінального процесу в мусульманському праві є те, що він не відмежовується і не має відмінностей від цивільного судочинства. Також примітним є те, що аж до другої половини VIII століття, поки до влади не прийшли Аббасіди, цивільні і кримінальні справи розглядалися без письмової фіксації ходу судочинства, тобто процес був усним [16, с. 70].

У Індонезії, наприклад, є три нетипові для нас теорії про закон доказування. Це теорії про тягар доказування обвинувачення, тягар доказування підсудного, тягар доказування, який збалансований $[17$, р. 822]. При цьому тягар доказування обвинувачення необхідно розуміти за аналогією iз нашим вітчизняним забезпеченням доведення вини, тягар доказування підсудного - як вітчизняне визнання вини, а тягар доказування, що збалансований, - як змагальність. На думку Северіуса Хулу, Діантота Сіманджунтак, Джошуа O.I Лімбонга та інших, існує теорія доказування «догори ногами». Це теорія, яка нав'язує обвинуваченому доказ, іншими словами, підсудний зобов'язаний довести, що він не допустив помилок, порушень чи злочинів, як стверджує прокурор [17, p. 827-828]. Цікавим є індонезійський підхід до окремих питань правового регулювання процесуальних джерел доказів. Законодавець оцінює показання експертів як один 3 важливих доказів при розгляді кримінальних справ [17, р. 829]. Тобто експертиза та показання експерта мають перевагу над іншими процесуальними джерелами доказів.

Поняття «документ» також містить елемент традиційності. Деталізується, що письмо - це те, що містить знаки, призначені для розуміння думки, які можна збагнути [17, р. 829]. Документом є предмет (може бути аркуш паперу, дерево, пальмовий листок тощо), який містить зрозумілу пунктуацію і виражає думку (створений на аркуші). Це регулюється лише однією статтею 187 , в якій зазначається, що такий документ має бути написаний під присягою та з підписом. Документ може сповіщати про подію або бути офіційним листуванням, здійсненим компетентним державним службовцем $[17$, с. 830]. Також у Індонезї як доказ використовується аналог вітчизняної експертизи у сфері права, за винятком того, що її сутність більш схожа на тлумачення права.

Необхідно також звернути увагу, що в Індонезії система кримінального правосуддя називається кримінально-правовим процесом, який починається 3 арешту, ув'язнення, обвинувачення та судового розгляду перед судом і закінчується виконанням кримінальних покарань у в'язниці [18, с. 82]. Тобто початок кримінального правосуддя в Індонезії визначається встановленням особи, яка вчинила кримінальне правопорушення.

В Ізраїлі англійська загальноприйнята закономірність послужила зразком для здійснення правосуддя, однак відбувся разючий відхід від неї, тобто відсутність присяжних. Система присяжних для досудових розслідувань і самого судового розгляду так і не була прийнята. Навіть у кримінальних справах суди складаються лише з професійних суддів. Це усуває деякі проблеми визначення відповідних функцій судді та присяжних. Відмінність між законом і фактом все ще має практичне значення, наприклад, в тому, що стосується здійснення апеляційної юрисдикції. Цей 
принцип полягає в тому, що апеляційні суди, як правило, розглядають лише питання права, відмінні від фактичних висновків. Ця відмінність також стосується кількох правил прохання і доказів [19, с. 1091].

У Нігерії діє Закон «Про адміністрування кримінального судочинства» (2015 р.) (далі - АСЈА). Примітно, що, хоча Закон є ґендерно чутливим, він все ще зберігає вживання чоловічих займенників (він, його та сам) в описі людини. У літературі визначено, що деякі міжнародні стандарти відсутні у АCJA, що вказує на традиційність окремих відносин, які досі існують у кримінальному процесі Нігерії. Зокрема, відсутні такі положення: положення, що забезпечують доступ дітей до правової допомоги на більш м'яких умовах, ніж дорослих; положення, що забезпечують право дитини на захисника (з метою представлення дитини від власного імені в процесі, коли існує або може виникнути конфлікт інтересів між дитиною та її батьками чи іншими залученими сторонами), а також на надання інформації про законні права у спосіб, відповідний віку та зрілості дитини, мовою, яку дитина може зрозуміти; положення про захист конфіденційності та особистих даних дитини, яка перебуває або яка була залучена до судових чи позасудових процедур та інших втручань; положення про надання правової допомоги навіть для свідків та вжиття адекватних заходів для забезпечення того, щоб свідки були негайно поінформовані про свої права на інформацію та право на допомогу і захист; положення щодо забезпечення права жінки на доступ до правової допомоги (включення гендерної перспективи у всі політики, закони, процедури, програми та практики, що стосуються правової допомоги) для забезпечення ґендерної рівності та рівного й справедливого доступу до правосуддя; положення, що стосуються використання активних заходів для того, щоб, де це можливо, адвокати-жінки могли представляти жінок-підсудних, обвинувачених та потерпілих; положення, що стосуються забезпечення справедливості у доступі до правової допомоги та спеціальних заходів не лише для жінок та дітей, а й груп з особливими потребами, таких як літні люди, люди з інвалідністю, люди 3 психічними захворюваннями, особи, які живуть з ВІЛ та іншими серйозними захворюваннями, наркозалежні, шукачі притулку, іноземні громадяни тощо [20, с. 76-77]; положення про те, що всі особи, які контактують 3 дітьми в системі кримінального правосуддя або несуть відповідальність за них, повинні отримувати освіту та навчання з прав людини, а також $з$ принципів, стандартів та норм ювенальної юстиції як невід’ємної частини їхніх навчальних програм тощо [20, p. 78].

Отже, на підставі аналізу наукових джерел були проаналізовані деякі нетипові для вітчиз- няного кримінального процесу особливості кримінально-процесуальних систем релігійно-традиційного типу. Можна сформулювати висновки про те, що кримінальний процес деяких країн засновується на традиціях, звичаях, релігійних нормах, а також враховує соціально-економічну формацію кожної країни. При цьому відбувається зближення усіх кримінальних процесів окремих країн (особливо тих, які географічно близькі) та гармонізація із міжнародними стандартами кримінального судочинства. Проте на такі процеси впливають економічні та соціокультурні реалії кожної окремої держави.

Також необхідно враховувати, що країни традиційного типу кримінального процесу більш лояльні до запозичення елементів кримінального процесу англо-американської (континентальної) правової системи, а країни релігійного типу таке запозичення здійснюють за умови повної трансформації релігійного типу у інший тип кримінального процесу.

\section{Jimepamypa}

1. Kolsky E. Codi cation and the Rule of Colonial Difference: Criminal Procedure in British India. Law and History Review. 2005. Vol. 23, No. 3 P. 631-683. DOI: $10.1017 / \mathrm{S} 0738248000000596$.

2. Anderson H. Justice Delayed in Malawi's Criminal Justice System Paralegals vs. Lawyers. International Journal of Criminal Justice Sciences. 2006. Vol 1 Issue 1 January. URL: http://www.sascv.org/ijcjs/ anderson.pdf.

3. Hahn J. Elliott. An Overview of the Japanese Legal System. Northwestern Journal of International Law \& Business. 1983. Vol. 5. Iss. 3. P. 517-539.

4. Соловьев С. А. Феномен благоприятствования в уголовном процессе зарубежных стран. Becmник Университета илени О.Е. Кутафина (МГЮА). 2018 № 01 (41). C. $230-238$. DOI: $10.17803 / 2311$ 5998.2018.42.2.230-238.

5. Appleton B. Richard, Far Eastern Section, Reforms in Japanese Criminal Procedure Under. Allied Occupation, Wash.L. Rev.\& St.B.J. 1949. 24. P. 401-430. URL: https://digitalcommons.law.uw.edu/ wlr/vol24/iss4/13.

6. Бирюков П.Н. Особенности совершения некоторых уголовно-процессуальных действий по праву Японии. Вестник Воронежского государственного университета. 2019. № 2. С. 298-304.

7. Циганюк Ю.В. Традиціоналізм у Кримінальному процесуальному кодексі Китайської Народної Республіки. Шістнадияті економіко-правові дискусї̈ (юридичне спрялування) : матеріали Міжнародної науково-практичної інтернет-конференції, м. Львів, 15 березня 2017 року. Львів, 2017. С. 73-75.

8. Ping Yu. Glittery Promise vs. Dismal Reality: The Role of a Criminal Lawyer in the People's Republic of China after the 1996 Revision of the Criminal Procedure Law. 2002. Vol. 35. P. 827-865. URL: https://www. researchgate.net/publication/265399514_Glittery Promise_vs_Dismal_Reality_The_Role_of_a_Criminal_ Lawyer in the_People's_Republic_of_China_afterthe 1996 Revision of the Criminal Procedure Law.

$\overline{9}$. Chu Mike $\overline{\mathrm{P}} \cdot \overline{\mathrm{H}}$. Criminal Procedure Reform in the People's Republic of China: The Dilemma of Crime 
Control and Regime Legitimacy. Pacific Basin Law Journal. 2000. 18 (2). P. 157-210.

10. Langer Máximo. Revolution in Latin American Criminal Procedure: Diffusion of Legal Ideas from the Periphery. The American Journal of Comparative Law. 2007. Volume 55, Issue 4. P. 617-676, DOI: 10.1093 / ajcl/55.4.617.

11. Стойко Н.Г., Гусейнова П.А. Особенности исламского порядка уголовного судопроизводства. Правоведение. 2014. № 2. С. 203-212.

12. Гусенова П.А. Исламский уголовный процесс: религиозно-правовая природа и характерные черты: на примере Исламской Республики Иран и Королевства Саудовская Аравия : дисс. ... канд. юридических наук : 12.00.09. Санкт-Петербург, 2016. 271 с.

13. Tellenbach S. Fair Trial Guarantees in Criminal Proceedings Under Islamic, Afghan Constitutional and International Law. Zeitschrift für ausländisches öffentliches Recht und Völkerrecht. 2004. 64. P. 929-941.

14. Arafa Mohamed A. Islamic Criminal Law: The Divine Criminal Justice System between Lacuna and Possible Routes. Journal of Forensic and Crime Studies. 2018. 2102 (Spring 2018). URL: https://ssrn.com/ abstract $=3189521$. DOI: $10.18875 / 2638-3578.2 .104$.

15. Robinson, P. H., Zulfiqar A., Kammerud M., Orchowski M., Gerlach E. A., Pollock A. L., O’Brien T. M.; Lin J. C., Stenson T., Katirai N.; Lee J. J., and Melzer, M. A. Codifying Shari'a: International Norms, Legality \& the Freedom to Invent New Forms. Faculty Scholarship. 2006. Paper 96. URL: http://scholarship.law.upenn.edu/ faculty scholarship/96.

16. Сизов А.А., Шахбазов Р.Ф. Состязательность в российском уголовном процессе: сравнительный анализ с судопроизводством в мусульманском праве. Изве стия Югозападного государственного университета. Серия «История и право». 2015. № 1 (14). С. 69-76.

17. Hulu S., Simanjuntak D., Limbong J. O.I, Sagala M.J.P., SH. MS, Penerapan Sistem Pembuktian Terbalik Dalam Tindak Pidana Pencucian Uang. Jurnal Darma Agung. 2019. Volume XXVII, Nomor 1. P.822-833.

18. Hanafi H., Pamuji R. A. Urgensi Keterangan Ahli Sebagai Alat Bukti Berdasarkan Sistem Peradilan Pidana di Indonesia. Al'Adl. 2019. Volume X Nomor 1, P. 81-90. URL: https://ojs.uniska-bjm.ac.id/index.php/ aldli/article/view/2020.

19. Eliaru Harnon. Criminal Procedure in Israel Some Comparative Aspects. University of Pennsylvania Law Review. 1967. Vol.115. P. 1091-1110. URL: http://scholarship.law.upenn.edu/cgi/viewcontent. cgi? article $=6218 \&$ context $=$ penn_law_review .

20. Ohiama R., Uruegi A., Bēkehnabeshe J. A Critique of the Nigerian Administration of Criminal Justice Act 2015 and Challenges in the Implementation of the Act. African Journal Of Criminal Law And Jurisprudence. 2019. 4. P. 69-81.

\section{Анотація}

Циганюк Ю. В. Окремі ознаки релігійно-традиційного типу системи кримінального процесу. - Стаття.

У статті розглянуто окремі ознаки релігійно-традиційного типу системи кримінального процесу. Автором визначено, що глобалізація та інтеграція відбуваються у різних правових системах, а це створює окремі наукові проблеми для їх вивчення, в тому числі юридичною наукою. Автором для дослідження обрано аналіз окремих ознак релігійно-традиційного типу кримінального процесу за допомогою ізолюючої абстракції самостійних і нетипових для континентальної системи кримінального процесу елементів.
Автор звернув увагу на окремі особливості таких країн, як Індія, Індонезія, Японія, Китай, Ізраїль, Нiгерія, Малаві, Афганістан, Іран і Саудівська Аравія. При порівнянні визначено деякі особливості систем кримінального процесу цих країн, які є атиповими для України.

На підставі аналізу наукових джерел проаналізовано деякі нетипові для вітчизняного кримінального процесу особливості кримінально-процесуальних систем релігійно-традиційного типу. Сформульовано висновки про те, що кримінальний процес цих країн засновується на традиціях, звичаях, релігійних нормах, а також враховує соціально-економічну формацію кожної країни. Автор визначив, що відбувається зближення усіх кримінальних процесів окремих країн (особливо тих, які географічно близькі) та гармонізація із міжнародними стандартами кримінального судочинства. Проте на такі процеси впливають економічні та соціокультурні реалії кожної окремої держави.

Автор зазначає про необхідність враховувати, що країни традиційного типу кримінального процесу більш лояльні до запозичення елементів кримінального процесу англо-американської (континентальної) правової системи, а країни релігійного типу таке запозичення здійснюють за умови повної трансформації релігійного типу у інший тип кримінального процесу.

Ключові слова: релігійно-традиційний тип кримінального процесу, система кримінального процесу.

\section{Summary}

Tsiganyuk Yu. V. Some features of the religioustraditional type of criminal process system. - Article.

The article deals with some features of a religioustraditional type of criminal process system. The author determines that globalization and integration occur in different legal systems, and this, accordingly, creates separate scientific problems for their study, including legal science. Accordingly, the author selected for the study the analysis of individual features of a religiouslytraditional type of criminal process using isolating abstraction of independent atypical elements for the continental system of criminal process.

The author drew attention to the specific features of countries such as India, Indonesia, Japan, China, Israel, Nigeria, Malawi, Afghanistan, Iran and Saudi Arabia. In comparison, some features of criminal systems of these countries that are atypical for Ukraine are identified.

As a result, on the basis of the analysis of scientific sources, some peculiarities of the criminal-procedural systems of the religious-traditional type were analyzed for the domestic criminal process. The conclusions are drawn that the criminal process of these countries is based on the traditions, customs, religious norms, and also takes into account the socio-economic formation of each country. The author has determined that there is a convergence of all criminal processes in individual countries (especially those that are geographically close) and harmonization with international standards of criminal justice. However, such processes are influenced by the economic and socio-cultural realities of each individual state.

The author notes that it is necessary to take into account that countries of the traditional type of criminal process are more loyal to borrow elements of the criminal process of anglo-american or continental legal systems, and countries of religious type carry out such borrowing on condition of complete transformation of religious type into another type of criminal process.

Key words: religious-traditional type of criminal process, system of criminal process. 